\title{
Ecological Problems Related to Mining-Metallurgical Industries and Innovatory, Energy-Efficient Ways of Solving Them
}

\author{
Guranda Jishkariani, Gigo Jandieri, David Sakhvadze, Giorgi Tavadze, \\ Garegin Zakharov Giorgi Oniashvili, Zurab Aslamazishvili \\ LEPL Ferdinand Tavadze Institute of Metallurgy and Material Sciences, Tbilisi, Georgia \\ Email: gigo.jandieri@yahoo.com
}

Received October 27, 2011; revised December 10, 2011; accepted December 17, 2011

\begin{abstract}
The below stated work scrutinizes ecological risks that are related to mining and metallurgical industries. It analyzes problems caused by pollution of air, soil and water and suggests new possible ways of resolving those problems. Namely, such innovative and energy-efficient technologies are argued as phytoremediation and exothermic self-propagating high-temperature synthesis of solid-phase recovery of metals (SHS). Visual arguments in support of the efficiency of the selected methods are provided.
\end{abstract}

Keywords: Ecology; Industrial Wastes; Phytoremediation; Metallothermic Recovery; Green Metallurgy

\section{Introduction}

The scale of anthropogenic impact onto the environment has become so immense that the life is about to face catastrophe. Presently there are approximately 2000 types of gases diffused in the atmosphere; hundreds of millions tones of liquid and solid industrial wastes are produced, that harm soil, water and atmospheric climate and have a negative impact on the health of the mankind.

Metallurgy, thermoelectric power, production of cement and concrete are one of the most hazardous productions for the world's ecology by being heavy-duty power industries. In any of the cases, products are made at the expense of carbon thermal oxidation inducing high temperature chemical reactions or burning of carbon-containing energy sources. Solid, liquid and gaseous energy sources are used as carbon-containing agents (Carbon, Cox, oil, natural gas). The average annual ratio of consumption of metallurgical Cox only amounts to 250 million tones. Therefore, emission of green house gases (such as $\mathrm{CO} ; \mathrm{CO}_{2} ; \mathrm{NO}_{2}$ ) in a present world, considering current state of industrial technologies and their capacity remains unsolved problem and an inevitable fact at a time. In this regard, another issue related to the metallurgical processing cycle of minerals which is accompanied by production of slag and its evacuation is also problematic. The share of slag in proportion to a net product equals to $200 \%-300 \%$.

To give an example, in one of the industrial parts of the Georgia, Zestaphoni, where a plant produces approximately 150,000 tones of silico-manganum annually (FeMnSi 17), 400,000 tones of slag is also being produced [1]. Together with other components, slag contains $10 \%$ $15 \%$ manganum and $2 \%$ of sulphur. About $60 \%$ of slag turns into granules by being poured into water tanks. What happens next is that, sulphur containing in the slag liberates as an anhydride $\left(\mathrm{SO}_{2}\right)$, which aerates in form of a dense cloud from the steam created as a result of granulation, then interfuses with a steam present in an atmospheric clouds and then, at the stage of condensation sulfuric acid is produced. Furthermore, precipitations containning sulphur acid pollute the environment for many kilometers ahead including lands for farming. This phenomenon is known as "Acid Stress" and amongst others is considered to be as yet another anthropogenic aggression turned against the ecology of nature. It is known that acid rains result in devastation of forests and agriculture [2]. Together with that, the number of babies who are born with inborn pathologies has increased dramatically.

It also should be considered that territories, formerly occupied by the Russian military forces in different regions of Georgia as well as numerous small and medium scale industrial objects that pollute soils, water and air with heavy metals, toxic organic substances, petroleum slag and radioactive substances create a threat not only to the health of Georgian population and ecosystem but also to the entire world. The biological peculiarities of the 
metals and radionuclides are such that they can accumulate in the human body and thus carry mutagenic, carcinogenic, teratogenic and embryotoxic threat in them $[3,4]$. Early methods and techniques used to remove metal pollutants from the soils, waters and air were inefficient, ecologically unsafe and expensive. In case of soil these technologies include excavation of contaminated layers, transportation, loading into special bioreactors or placing in sections isolated from atmospheric sediments, which is a high workload and expensive process. It's been studied that, decontamination of 1 acre (4046.86 square $\mathrm{m}$.) of land from plumbum through phytoremediation to reach the depth of $50 \mathrm{~cm}$ costs approximately $60 \$$ - 100\$, whereas, the excavation and relocation of the same amount of land will cost $\sim 1.700 \$[5]$.

\section{Innovatory, Energy-Efficient Ways of Solving Ecological Problems}

1) Phytoremediation is one of the most innovative, cost-effective and energy-efficient methods of decontaminating and recovering chemically polluted environment. This method implies selecting and cultivating plants with high accumulative capacities in polluted areas with abilities to selectively absorb undesirable chemical elements and compounds and transfer them into biomass. Phytore-mediation is also known as green filtration method [6-8].

Phitoremediation simultaneously represents remediative, maintenance and preventive action, as it enables not only restoration of chemically contaminated environment, but also long-time limitation or entire avoidance of toxic spreading from contaminated sources. Planned planting of green cover also protects ground from exhaustion and erosion [9].

The high efficiency of the technology of biological purification of soils, waters and air that we suggest is predetermined by the fact that the plants used in phytoremediation process are characterized with high capacity to accumulate heavy metals. The plants will be selected from the local species based on preliminary stud ies due to the fact that their accumulative abilities are affected by the $\mathrm{pH}$ of the soil and other biological conditions. Simplicity and cost effectiveness of phytoremediation lies in the systematic planting of certain types of plants into the polluted soils and also in the application of regular agro-technical methods. The plants can be both of one year and of a mixed typology. Most importantly, they should possess high accumulative abilities to decontaminate and purify the environment from as many pollutants as possible. Phytoremediation process is universal and is applicable to any polluted object or site as plants can absorb different chemical and toxic compounds and thus decontaminate not only soil but also water and air. Different phytoremediation methods are used to remove pollutants from the soil, water and air. Green filtration is a technology applied to purify polluted air that prevents the spreading of greenhouse gas emissions coming from the highways and factories.

In this regard, the following perennial trees have proved to be successful: Aesculus hippocastanum, Quercus, Salix, Pinus Eldarica, Acer, Alnus. The trees not only accumulate metals in their leaves and roots, nonorganic and organic substances, but also absorb emission of toxic gases from factories, chemical and military industries and automobiles. They are taking active part in general metabolic process and namely in assimilation of exhaust gases, such as carbon and nitrogen oxides- $\mathrm{CO}$, $\mathrm{CO}_{2}, \mathrm{NO}_{2}$. The trees absorb and accumulate them with leaves and roots. As to $\mathrm{CO}$, it develops until $\mathrm{CO}_{2}$, and then enters into photosynthesis process, which is acelerated by the sunlight. Rhizofiltration is applied to decontaminate and purify subterranean springs and water reservoirs from heavy metals and radionuclides. Different plants are being applied to extract heavy metals, radionuclides and organic substances, such as genetically modified Populous Tremula L. and Eichornia. Phytotransformation and phytostabilization are applied to remove organic pollutants from both soil and water. In the process of phytostabilization organic and non organic pollutants are being transformed into less active forms, thus their hazardous impact on to the nature is minimized.

Some of the widely used hyper accumulative vegetation is listed in Table 1. Statistics for comparative ecological contamination of areas adjacent to densely populated urban areas and cities of Georgia can be seen in Table 2. Results of studies carried out using LMA laserspectral analyzer and Analist -800 Perkin Elmer nuclearabsorbing spectrometer for determining definite figures of heavy metal contamination are presented in Figure 1, Tables 3 and 4. And titles and time of planting for our selected vegetation are listed in Table 5.

In our case special attention was paid to studying territories in radius of $30 \mathrm{~km}$ around copper and gold mines (Quartzite LTD and Madneuli LTD) of carrier types. This territory is used for agricultural irrigation means and is irrigated by Mashavera river, where mine waters flow in. This aspect increased urgency of our planned study.

Next stage included selection of effecttive steel-accumulating vegetations for this territory-familiar for local climate conditions and contamination type-as possible candidates for cleansing the contaminated soil. In case of heavy metals, for phytoremediation procedures we used the hyperaccumulative vegetation, selected prior from the local flora, as vegetation possessing hyperaccumulative features for heavy metals have difficulty in getting used to new soil and climate zones (Table 5).

Analyses were compared to the maximum permissible 
Table 1. Plants applied in phytoremediation to decontaminate soils polluted with heavy metals.

\begin{tabular}{|c|c|}
\hline Plants & Extracted Heavy metals \\
\hline Silene vulgarisi & $\mathrm{Zn}$ \\
\hline Thlaspi caerulescens & $\mathrm{Zn}, \mathrm{Cd}$ \\
\hline Brassca juncea & $\mathrm{Pb}, \mathrm{Cr}, \mathrm{Cd}, \mathrm{Ni}, \mathrm{Zn}, \mathrm{Cu}$ \\
\hline Helianthus annuus & $\mathrm{Cu}, \mathrm{Cd}, \mathrm{Cr} . \mathrm{Ni}, \mathrm{Pb}, \mathrm{Zn}$ \\
\hline Polygonum & $\mathrm{Cd}, \mathrm{Pb}, \mathrm{Zn}, \mathrm{Ni}$ \\
\hline Festuca ovina & $\mathrm{Pb}$ \\
\hline Zea mays & $\mathrm{Cd}, \mathrm{Cu}, \mathrm{Ni}, \mathrm{Zn}, \mathrm{As}, \mathrm{Pb}$ \\
\hline
\end{tabular}

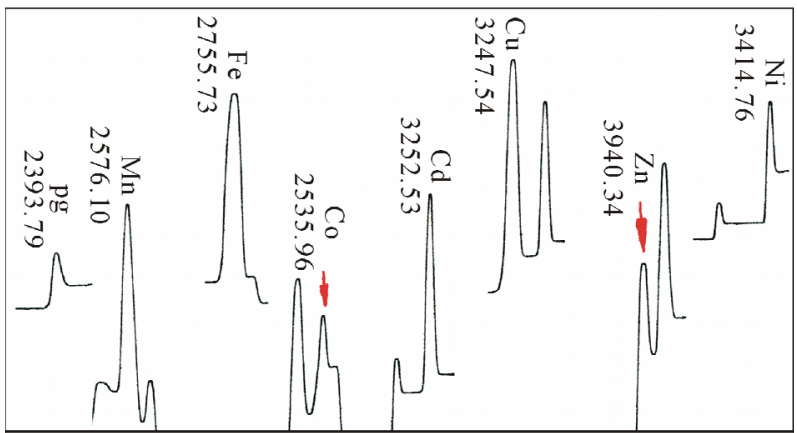

Figure 1. Laser spectrogram of soil contaminated by Mashavera river.

concentration. Special attention was paid to analysis of the metals movable in soil, accessible to vegetation and easily absorbed. After around 2 months of planting, we inserted into soil effectors of phytoextraction - self-renewable substance Ethylenediaminetetraacetic acid (Figure 2), which greatly increases accumulation of metals in the upper soil biomass. After completion of the initial laboratory research, experiments will be carried out in natural environment, and finally - in field conditions.

Figure 3 presents various metal salt granules concentrated and crystallized in stem fibers of Sea meys and Helianthus tuberosus. This clearly indicates that vegetation managed to absorb chelate water solutions emerged as a result of EDTA effect. Microscopic images were taken after completion of vegetation period and their drying up on air. Results of analytical study of soil upon completion of the first stage of phytoremediation can be seen on Table 6. Brackets indicate contamination variation in mass percentage. As these results show, Sea meys and Leonurus cardiac possess highest copper and zinc extraction ability; Leonurus cardiac and Sea meys are best extractors for cadmium; Hebianthus tuberosus is the best absorber of lead and manganum; Artemisia absinthium and Linum autriacum have best extraction ability of nickel.

It is also essential to apply hydraulic control. It is a preventive activity that refers to growing and spreading

Table 2. Soils polluted with heavy metals in Georgian cities and villages.

\begin{tabular}{cccccccc}
\hline \multirow{2}{*}{$\#$} & Populated cities & \multicolumn{5}{c}{ Heavy metals concentration, $\mathrm{mg} / \mathrm{kg}$} \\
\cline { 3 - 7 } & & $\mathrm{Pb}$ & $\mathrm{Cu}$ & $\mathrm{Zn}$ & $\mathrm{Mn}$ & $\mathrm{Ni}$ & $\mathrm{Cr}$ \\
\hline \multirow{2}{*}{2} & Tbilisi & $33.0-65.4$ & $157-270$ & $197-400$ & $750-1100$ & $107-140$ & $132-280$ \\
2 & Rustavi & $56.0-140.0$ & $88.0-160$ & $113-200$ & $1082-1400$ & $70.0-180$ & $123-200$ \\
3 & Zestafoni & $10.0-69.0$ & $54.0-200$ & $80.0-190$ & $1300-2600$ & $126-186.9$ \\
4 & Kutaisi & $44.8-279$ & $45.5-100$ & $81.0-116.7$ & $739.6-1089$ & $61.5-122.5$ & $64.4-114.5$ \\
5 & Batumi & 10.0 & $118.0-123.8$ & $99.0-132.7$ & $533-1333$ & & \\
& M.P.C. & 32.0 & 3.0 & 23.0 & 1500 & 4.0 & 9.0 \\
\hline
\end{tabular}


Table 3. Containment of metals in soil $(\mathrm{mg} / \mathrm{kg})$.

\begin{tabular}{cccc}
\hline № & Title & Containment & $\begin{array}{c}\text { Maximum permissible } \\
\text { concentration }\end{array}$ \\
\hline 1 & $\mathrm{Cu}$ & 951.0 & 10.0 \\
2 & $\mathrm{Zn}$ & 732.1 & 38.0 \\
3 & $\mathrm{Cd}$ & 4.901 & 0.2 \\
4 & $\mathrm{~Pb}$ & 22.85 & 11.0 \\
5 & $\mathrm{Mn}$ & 637.5 & 50.0 \\
6 & $\mathrm{Fe}$ & 83.14 & \\
7 & $\mathrm{Co}$ & 21.50 & 4.0 \\
8 & $\mathrm{Ni}$ & 24.44 & 2.0 \\
\hline
\end{tabular}

Table 4. Samples of water from irrigation channel serving the territory (mg/l).

\begin{tabular}{cccc}
\hline № & Title & Factual amount & $\begin{array}{c}\text { Maximum permissible } \\
\text { concentration }\end{array}$ \\
\hline 1 & $\mathrm{Cu}$ & 2.470 & 1.0 \\
2 & $\mathrm{Zn}$ & 1.262 & 1.0 \\
3 & $\mathrm{Fe}$ & 4.633 & 0.3 \\
4 & $\mathrm{Mn}$ & 0.752 & 0.1 \\
5 & $\mathrm{Co}$ & 0.019 & 0.01 \\
6 & $\mathrm{Ni}$ & 0.020 & 0.1 \\
7 & $\mathrm{~Pb}$ & 0.032 & 0.03 \\
\hline
\end{tabular}

Table 5. Selected vegetation and time of their planting.

\begin{tabular}{lc}
\hline \multicolumn{1}{c}{ Type of vegetation } & Date of planting \\
\hline Sea meys & 20.04 .2011 \\
Helianthus annuus & 20.04 .2011 \\
Brassica juncea & 27.04 .2011 \\
Hebianthus tuberosus & 2.05 .2011 \\
Artemisia absinthium & 10.05 .2011 \\
Capsella bursapastorismedis & 11.05 .2011 \\
Linum autriacum & 17.05 .2011 \\
Leonurus cardiaca & 26.05 .2011 \\
\hline
\end{tabular}

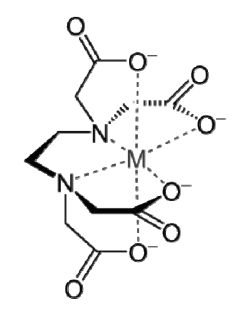

Figure 2. Metal-EDTA chelate.

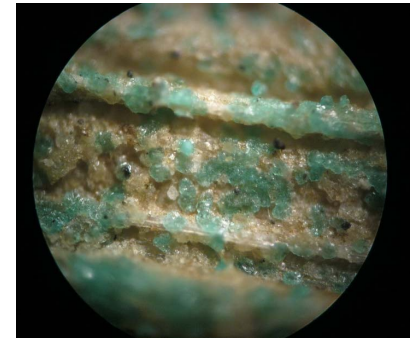

(a)

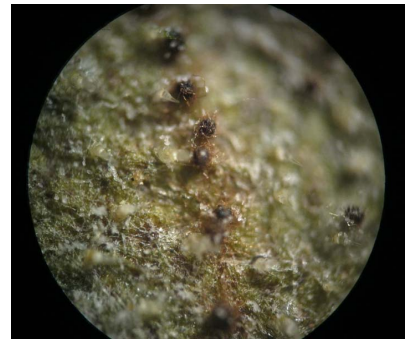

(b)
Figure 3. Microscopic shot of metal compounds removed from polluted soil by means of Phytoremediation, $\times 100$. (a) “Zea mays", Copper minerals in a plant's stalk; (b) “Hebianthus tuberosus", Cadmium, zinc and plumbum minerals in a leaf of a plant.

of plants with high transpiration ability. The plants absorb high volume of water with toxic agents present in them. Through absorption the plants curb further spreading of the pollutants from the polluted site.

It is recommended to create vegetative cover systems. They are applied to permanently polluted zones to curb the spreading of pollutants deep into soil. Cultivation of waterside protective corridors is also recommended, in areas with a risk where pesticide residues or other toxic agents may dissolve in the water.

Application of the above-mentioned methods of phytoremediation are believed to significantly reduce the consistency of heavy metals, oil slag, toxic organic compounds and gas exhausts in the environment. All of this, in its turn, will sanitize the ecology of the environment and improve the health of the population, will ensure sustainability and development of the environment.

Despite of the evident benefits of phytoremediation method, its direct application to the areas where hundreds of thousands tones of industrial waste are aggregated is infeasible, due to inexistence of essential conditions necessary for plants to grow. Only when industrial wastes are reduced to the minimal degree where plants can develop their root systems, can the method be applied.

Together with proposed methods of improvement of the environmental ecology the modern world community must make every effort to force energy-consuming industries that threaten the ecological balance of our planet to switch to the application of less harmful technologies.

It implies replacement of melting aggregates that use carbon-containing energy sources (such as: Cupola, small blast, fuel fiery and Martin furnaces) with modern type furnaces such as induction and plasma (PAF) ones; replacement of carbon-recuperating metallurgical processes with self-propagating high-temperature metallothermic synthesis $[10,11]$; application of micro-biological methods to recycling of waste [12]; modernization of aspirating and gas filtrating equipment with nanotechnologies and so on. 
Table 6. Metal containing data of soil after phytoremediation process (mg/kg).

\begin{tabular}{|c|c|c|c|c|c|c|c|c|c|}
\hline \# & Metall & Sea meys & $\begin{array}{l}\text { Helianthus } \\
\text { annuus }\end{array}$ & Brassica juncea & $\begin{array}{l}\text { Hebianthus } \\
\text { tuberosus }\end{array}$ & $\begin{array}{l}\text { Artemisia } \\
\text { absinthium }\end{array}$ & $\begin{array}{c}\text { Capsella } \\
\text { bursapastorismedis }\end{array}$ & $\begin{array}{c}\text { Linum } \\
\text { autriacum }\end{array}$ & $\begin{array}{l}\text { Leonurus } \\
\text { cardiaca }\end{array}$ \\
\hline 1 & $\mathrm{Cu}$ & $\begin{array}{c}271.8 \\
(-71.4 \%)\end{array}$ & $\begin{array}{c}631.3 \\
(-33.6 \%)\end{array}$ & $\begin{array}{c}774.0 \\
(-18.12 \%)\end{array}$ & $\begin{array}{c}515.7 \\
(-47.67 \%)\end{array}$ & $\begin{array}{c}444.10 \\
(-53.3 \%)\end{array}$ & $\begin{array}{l}525.1 \\
(-44.78 \%)\end{array}$ & $\begin{array}{c}702.1 \\
(-26.17 \%)\end{array}$ & $\begin{array}{c}388.1 \\
(-59.19 \%)\end{array}$ \\
\hline 2 & $\mathrm{Zn}$ & $\begin{array}{c}288.1 \\
(-60.6 \%)\end{array}$ & $\begin{array}{c}660.4 \\
(-9.7 \%)\end{array}$ & $\begin{array}{c}718.8 \\
(-1.82 \%)\end{array}$ & $\begin{array}{c}603.5 \\
(-17.5 \%)\end{array}$ & $\begin{array}{c}707.1 \\
(-3.40 \%)\end{array}$ & $\begin{array}{c}683.1 \\
(-6.60 \%)\end{array}$ & $\begin{array}{c}628.2 \\
(-14.19 \%)\end{array}$ & $\begin{array}{c}540.1 \\
(-26.22 \%)\end{array}$ \\
\hline 3 & $\mathrm{Cd}$ & $\begin{array}{c}2.335 \\
(-52.36 \%)\end{array}$ & $\begin{array}{c}2.610 \\
(-46.74 \%)\end{array}$ & $\begin{array}{c}2.510 \\
(-48.78 \%)\end{array}$ & $\begin{array}{c}2.841 \\
(-42.03 \%)\end{array}$ & $\begin{array}{c}2.515 \\
(-48.68 \%)\end{array}$ & $\begin{array}{c}2.572 \\
(-47.52 \%)\end{array}$ & $\begin{array}{c}2.511 \\
(-48.76 \%)\end{array}$ & $\begin{array}{c}1.993 \\
(-59.25 \%)\end{array}$ \\
\hline 4 & $\mathrm{~Pb}$ & $\begin{array}{c}11.94 \\
(-47.74 \%)\end{array}$ & $\begin{array}{c}12.61 \\
(-44.81 \%)\end{array}$ & $\begin{array}{c}12.15 \\
(-46.83 \%)\end{array}$ & $\begin{array}{c}7.577 \\
(-66.84 \%)\end{array}$ & $\begin{array}{c}12.52 \\
(-45.21 \%)\end{array}$ & $\begin{array}{c}14.06 \\
(-38.47 \%)\end{array}$ & $\begin{array}{c}12.36 \\
(-45.91 \%)\end{array}$ & $\begin{array}{c}12.12 \\
(-46.96 \%)\end{array}$ \\
\hline 5 & Mn & $\begin{array}{c}156.7 \\
(-75.42 \%)\end{array}$ & $\begin{array}{c}583.0 \\
(-8.55 \%)\end{array}$ & $\begin{array}{c}379.6 \\
(-40.45 \%)\end{array}$ & $\begin{array}{c}121.7 \\
(-80.91 \%)\end{array}$ & $\begin{array}{c}519.9 \\
(-18.45 \%)\end{array}$ & $\begin{array}{c}591.7 \\
(-7.18 \%)\end{array}$ & $\begin{array}{c}571.6 \\
(-10.34 \%)\end{array}$ & $\begin{array}{c}469.9 \\
(-26.29 \%)\end{array}$ \\
\hline 6 & $\mathrm{Ni}$ & $\begin{array}{c}19.14 \\
(-21.68 \%)\end{array}$ & $\begin{array}{c}20.12 \\
(-17.68 \%)\end{array}$ & $\begin{array}{c}17.23 \\
(-29.50 \%)\end{array}$ & $\begin{array}{c}17.85 \\
(-26.96 \%)\end{array}$ & $\begin{array}{c}16.38 \\
(-32.98 \%)\end{array}$ & $\begin{array}{c}18.36 \\
(-24.88 \%)\end{array}$ & $\begin{array}{c}16.73 \\
(-31.55 \%)\end{array}$ & $\begin{array}{c}17.49 \\
(-28.44 \%)\end{array}$ \\
\hline
\end{tabular}

2) Among many possibilities described above, in terms of energy-efficiency and ecological safety the preference should nevertheless be given to the replacement of carbon-recovering metallurgical processes with self-propagating high temperature syntheses (SHS), namely solidphase metallothermic recovery technologies, which apart from eliminating carbon-containing reductants minimize the waste of electric-power [13].

Chemical scheme for obtaining (reconstructing) materials can be presented in following form:

$$
\sum_{i=1}^{N 1} v_{i} A_{i}+\sum_{j=1}^{N 2} v_{j} B_{j}+\sum_{k=1}^{N 3} v_{k} C_{k}=\sum_{m=1}^{M 1} v_{m} D_{m}+\sum_{n=1}^{M 2} v_{n} E_{n}+Q
$$

where

$A_{i}$ : technogenic waste comprised of $\mathrm{MnO}, \mathrm{MnO}_{2}, \mathrm{SiO}_{2}$ etc.;

$B_{j}$ : metal oxides $\left(\mathrm{Cr}_{2} \mathrm{O}_{3}, \mathrm{~V}_{2} \mathrm{O}_{5}\right.$ etc. $)$;

$C_{k}$ : restoring metals (AI, $\mathrm{Mg}$ );

$D_{m}$ : obtained phase (MnSi-VGr etc.);

$E_{n}$ : obtained oxide phase $\left(\mathrm{Al}_{2} \mathrm{O}_{3}\right.$, Spinels);

$v_{i}, v_{j}, v_{k}, v_{m}, v_{n}$ : stecheometric coefficients of reagents and product quantity.

Spread of reactive mass $\Delta m(\%)$ was registered in experiments according to the following formula:

$$
\Delta m=\left(m_{i}-m_{k}\right) 100 / m_{k}
$$

where

$m_{i}$ : mass of initial product;

$m_{k}$ : mass of end product.

Extracting of main admixture component has been calculated via the following formula:

$$
M=m_{c} k_{o} 100 /\left(m_{c} k_{o}+m_{h} c_{o}+m_{g} n_{o}\right)
$$

where

$m_{c}$ : mass of metal pile of the end product;

$k_{o}$ : composition of the main admixture component in pile, as $\%$ of the mass; $m_{h}$ : mass of slag;

$c_{o}$ : composition of the main admixture component in slag, as \% of the mass;

$m_{g}$ : of condensed product, approximating to difference in weight of the sample mass before and after synthesis;

$n_{o}$ : composition of main admixture component in condensed product, as $\%$ of the mass.

In SHS mode various chemical, physical and physicalchemical processes take place. During obtaining process of admixtures, a redux reaction takes place with subsequent structure emergence. Based on the prior experimental results, possibility of obtaining wide class of admixtures and modificators via the SHS method. Innovation of these developments lies is technological solutions that enable obtaining of cheap materials via SHS process. These materials are based on usability as component of initial technogenic waste products, including manganese (Figure 4).

The above-mentioned technology has been elaborated by us to recycle small-fraction mining-metallurgical waste that contains iron oxides and manganum. Multi compound complex alloys have been obtained containing Fe$\mathrm{Mn}-\mathrm{Si}-\mathrm{Cr}-\mathrm{V}-\mathrm{Ti}-\mathrm{Ni}-\mathrm{Nb}-\mathrm{W}-\mathrm{Al}-\mathrm{Na}$ (reducing agents, modifiers and ligatures).

The end products were studied via method of chemical and phased $\mathrm{x}$-ray analysis. Common end product exit amounts to $95 \%$. Extracting of main elements amounted to $92 \%$.

In steel production, application of metallothermic briquettes instead of deoxidizing and alloying ferro-compounds is considered to be a promising perspective $[14,15]$.

In these types of briquettes instead of metal components, their oxides are used (in form of an ore), while as a recovering agent, in this case also, an active metal (e.g. Aluminum) for the particular elements is being applied instead of carbon. The above-mentioned, is aiming at metal composition synthesis directly within alloy which 


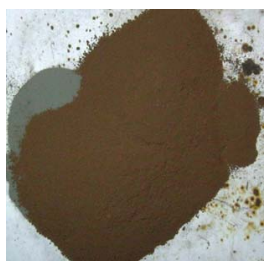

(a)

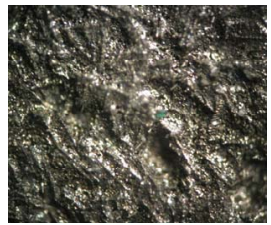

(d)

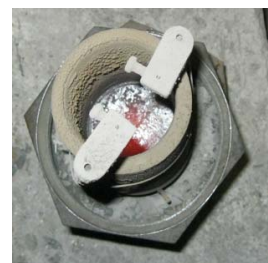

(b)

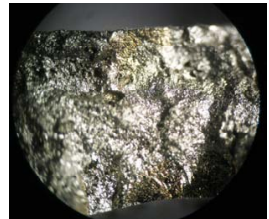

(e)

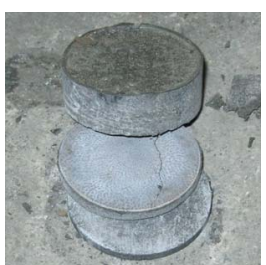

(c)

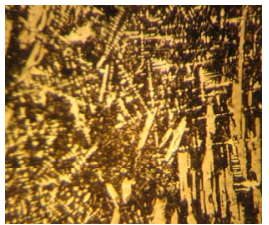

(f)
Figure 4. Restoring metals and obtaining complex alloys from powder oxide industrial waste via the SHS method. (a) Reactive mixture of powder industrial waste of manganese and silicium rust with metal aluminum; (b) SHS processing of waste; (c) Obtained metal alloy and slag of restoration process (Korund, Spinel); (d) Surface of metal alloy $(\times 50)$; (e) breaking-off of metal alloy $(\times 10)$; (f) Microstructure of metal alloy $(\times 100)$.

is to be processed (steel, cast iron) and is achieved through provision of briquette in a liquid alloy (Figure 5).

An example for manganese-containing rust and carbonate waste from mountainous metallurgical industry is provided: During the heating of oxide waste to $150^{\circ} \mathrm{C}$ the waste dehydration, drying up (including removal of hygroscopic water) takes place, while heating from $600^{\circ} \mathrm{C}$ to $1060^{\circ} \mathrm{C}$ is followed by following phase transitions:

$$
\begin{aligned}
& \mathrm{MnOOH} \cdot \mathrm{H}_{2} \mathrm{O} \stackrel{/ 60-150 /}{\longrightarrow} \mathrm{MnOOH} \stackrel{/ 150-600 /}{\longrightarrow} \\
& \mathrm{Mn}_{2} \mathrm{O}_{3} \stackrel{/ 920-1060 /}{\longrightarrow} \mathrm{Mn}_{3} \mathrm{O}_{4}
\end{aligned}
$$

If the waste is carbonated, carbon mixture dissociation and seclusion as volatiles takes place:

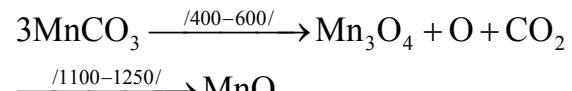

In state of aluminum accompaniment the following redux reactions take place:

$$
\begin{aligned}
& 2[\mathrm{Al}]+3[\mathrm{O}]=\mathrm{Al}_{2} \mathrm{O}_{3} \\
& \left(\mathrm{Al}_{2} \mathrm{O}_{3}\right)+3(\mathrm{MnO})=3\left(\mathrm{MnO} \cdot \mathrm{Al}_{2} \mathrm{O}_{3}\right) \\
& 3\left(\mathrm{MnO} \cdot \mathrm{Al}_{2} \mathrm{O}_{3}\right)+2[\mathrm{Al}]=3[\mathrm{Mn}]+2\left(\mathrm{Al}_{2} \mathrm{O}_{3}\right)
\end{aligned}
$$

Restoration of manganum rust and transition to metal is carried out by rusting aluminum.

Thermal impact of high-temperature liquid mass $\left(1400^{\circ} \mathrm{C}\right.$ - $1500^{\circ} \mathrm{C}$ ) induces recovering metal agent in briquette, which in its turn, carries on self-propagating metalthermal reaction. Aluminum starts to oxidize through joining

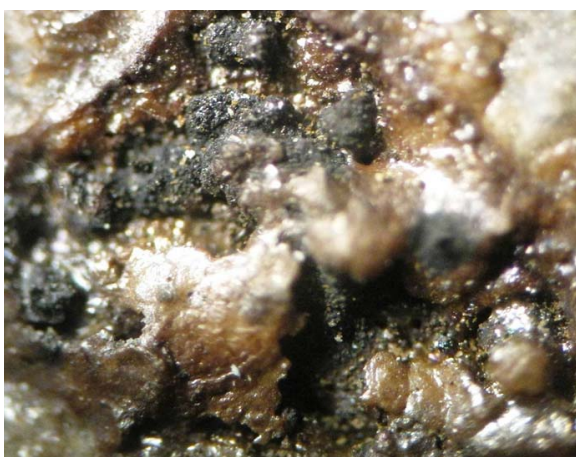

(a)
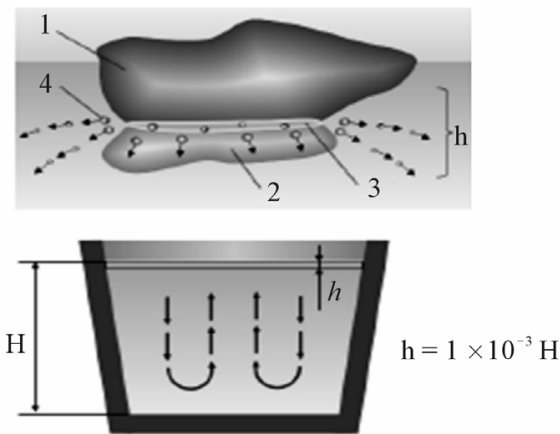

(b)

Figure 5. Activization of metallothermic SHS briquettes in liquid steel. (a) Self-recovery of metals $(\mathrm{Mn}-\mathrm{V}), \times 50$; (b) Schematic model; $1-$ Oxidic phase of reducing alloying element; 2-Reducer (aluminium); 3-Zone of exothermic reaction in the briquette; 4-Drops of reduced metallic element; $h-Z o n e$ of reduction and deposition of alloying element from briquettes to ladles; $\mathrm{H}$-Filling level of ladle by treating liquid steel.

with the existing oxides in the ore. In a process, desirable metal elements recover until reaching condition of metal. As a result of reaction, synthesized metal and non-metal phases produced through oxidization of aluminum and with natural gravitation impact are separated and automatically partitioned in the alloyed metal and slag layers meant for processing.

It is important to note that on current stage of research these developments possess technological reserves; main synthesis parameters and ways of increasing material quality for increasing technical-economical preferences of the developed technology have been determined. It is also important to note that all manganese-containing end products obtained via SHS method and used as components in initial mixture possess potential for industrial usage. This is determined by the fact that the SHS technology allows for obtaining materials by such parameters as freshness, quality, exit and extraction of product, which are not possible to obtain via traditional methods of metal thermos [16,17] and electrothermos [18,19].

The results of research will have an utmost importance for both: environment protection and sustainable devel- 
opment of economic and industrial potential.

\section{Conclusion}

To sum up, today, as never before the world population needs to develop eco-friendly thinking and culture. When on the verge of making just about any new technological decision, technological processes should only be planned with an utmost consideration of ecological safety issues. Suggested technologies to solve ecological problems caused by mining and metallurgical industries are 20, 30 times cheaper, simple and ecologically safer compared to the methods existing before. Those methods not only represent innovative, energy-efficient means of recuperating and recycling useful elements but also create new possibilities for waste-free production on a global scale. Therefore, the methods that we suggest are perceived by us as avant-garde and alternative ways for the economic development, which can be called and referred to as green metallurgy.

\section{REFERENCES}

[1] G. Jandieri, D. Sakhvadze and G. Tavadze, "The Current State and Prospects of Manganese Ferroalloy Production in Georgia," Journal of Metallurgicheskoe i Gornorudnoe Promishlennost, Vol. 3. 2011. pp. 34-37. In Russia.

[2] R. Carrete, M. T. Vidal, A. Bordons, M. Constanti, "Inhibitory Effect of Sulfur Dioxide and Other Stress Compounds in Wine on the ATPase Activity of Oenococcus oeni," FEMS Microbiology Letters, Vol. 211, No. 2, 2002, pp. 155-159. doi:10.1007/s11015-006-0107-5

[3] V. Saakadze, "Occupational Medicine," Edition "Zekari," Tbilisi, 2000, p. 806.

[4] M. Tsimakuridze, V. Saakadze and M. Tsereteli, "Urgent Problems of Occupational Diseases in Georgia in the Junction of XX-XXI Centuries," Georgian Medical News, Vol. 6, No. 159, 2008, pp. 62-68.

[5] J. W. Huang, J. Chen and S. D. Cunningham, "Fytoremediation of Soil and Water Contaminants," American Chemical Society, Vol. 21, 1997, pp. 283-298.

[6] S. M. Dushenkov, Y. Kapulnik and M. Blaylock, "Phytoremediation: A Novel Approach Toan Old Problem," In: D. L. Wise, Ed., Global Enviromental Biotechnology, Elsevier Science, Amsterdam, 1997. pp. 563-572.

[7] G. E. Boyajian and D. L. Devedjia, "Phytoremediation: It Grows on You," Soil \& Groundwater Cleanup, 1997, pp. 22-26.
[8] J. Haensler, "Phytoremediation Schwermetallbelasteter Böden durch Einjährige Pflazen in Einzel-und Mischkultur," Inaugural-Dissertation zur Erlangung des Doktorgrades der Mathematisch-Naturwissenschaftlichen Fakultät der Heinrich-Heine-Universität, Düsseldorf, 2003.

[9] G. Jishkariani, M. Mikaberidze, D. Sakhvadze and G. Tavadze, "Cleaning-Reduction of the Soils Polluted by Heavy Metals via the Phytoremediation Method," Ceorgia Chemical Journal, Vol. 10, No. 4, 2010, pp. 95-105.

[10] S. E. Matinyan, 1. S. Abovyan, A. B. Harutyunyan and S. L. Kharatyan, "Co-Reducing of $\mathrm{Cr}_{2} \mathrm{O}_{3}$ and $\mathrm{Fe}_{2} \mathrm{O}_{3}$ under the Combustion Mode and SHS of Cast Ferrochrome Alloys," Chemical Journal of Armenia, Vol. 60, No. 3, 2007, pp. 382-394.

[11] E. V. Pugacheva, V. N. Borshch, S. Ya. Zhuk, V. N. Sanin and D. E. Andreev, "Polymetallic Catalysts of Deep Oxidation of $\mathrm{CO}$ and Hydrocarbons for Purification of Waste Gases," 14th International Congress on Catalysis, Seoul, 13-18 July 2008, p. 472.

[12] D. Sakhvadze, G. Tavadze, L. Sakhvadze, G. Jandieri, A. Raphava and R. Gigauri, "Deterimental Effect of Technogene on Environment and Its Utilization by Biotechnological Method," Georgia Chemical Journal, Vol. 10, No. 4, 2010, pp. 2-7.

[13] A. G. Merzhanov, I. P. Borovinskaya and V. M. Shkiro, "Wavelike Localization of Auto-Braking Hard Phased Reactions," USSR State Registry of Discoveries, 1967. http://ross-nauka.narod.ru/05/05-287.html

[14] O. S. Bobkova and V. V. Barsegyan, "Prospects of Technologies for the Direct Alloying of Steel from Oxide Melts," Metallurgist, Vol. 50, No. 9-10, 2006, pp. 463468. doi:10.1016/S0378-1097(02)00687-0

[15] G. Jandieri, T. Surguladze, D. Robaqidze, M. Shalamberidze and B. Shchukin, "Control of the Process of Direct Manganese Alloying of Alloy," Metal Science and Heat Treatment, Vol. 51, No. 11, 2009, pp. 536-539.

[16] A. S. Degay, "All Way of Melt of the Steel," Russia Patent No. 2194772, 2002.

[17] K. G. Pugin and V. S. Yushkov, "Fine Iron-Rich Ferrous Metallurgical Dust Recycling," 2010. http://waste.ua/cooperation/2010/theses/pugin.html\#Pugi $\mathrm{n}$

[18] B. P. Krikunov, D. V. Kolesnikov and A. I. Dreyko. "Waste Recovery Methods and Cost Reduction in the Metallurgy," Metallurgical and Mining Industry, Vol. 4, 2011, pp. 124-128.

[19] R. Kononov, O. Ostrovski and S. Ganguly, "Carbothermal Solid State Reduction of Manganese Ores," 2007. http://www.pyrometallurgy.co.za/InfaconXI/027.pdf 